\title{
PENGARUH AUSTEMPER DUCTILE IRON TERHADAP KEKERASAN DAN STRUKTUR MIKRO DUCTILE CAST IRON ( FCD-45 )
}

\author{
Fredek Demianus Balubun, Suriansyah S. \\ Jurusan Teknik Mesin Universitas Widya Gama Malang \\ Email : $\underline{\text { mesin@widyagama.ac.id }}$
}

\begin{abstract}
ABSTRAK
Perkembangan ilmu pengetahuan dan teknologi saat ini membawa dampak yang begitu besar bagi perkembangan teknologi. Seiring kemajuan industri berbagai kebutuhan terhadap material telah memaksa manusia untuk berinovasi, sehingga material yang paling banyak digunakan di dunia industri adalah baja, karena baja memiliki keunggulan yaitu kekuatan yang tinggi, kemampukerasan yang baik. Pada perkembangannya penggunaan material baja diimbangi dengan semakin banyaknya pengunaan material besi cor. Hal ini terjadi karena besi cor memiliki keunggulan, yaitu bahan yang relatif murah, mampu cor yang baik, dan juga mampu mesin yang relatif lebih baik. Maka penelitian ini bertujuan untuk mengetahui pengaruh austemper ductile iron terhadap kekerasan dan struktur mikro. Penelitian ini menggunakan besi cor nodular FCD 45, dengan pengujian pertama yaitu quenching udara dan oli terhadap kekerasan dan struktur mikro. Variasi pemanasan yang digunakan 6000 C - 9000 C dengan penahanan waktu 45 menit/ 1 jam. Pengujian kedua sebagai pembanding dengan variasi besi cor nodular FCD 45 tanpa perlakuan. Hasil penelitian menunjukkan bahwa pada besi cor FCD 45 variasi tanpa perlakuan lebih cenderung mengalami penurunan kekerasan yaitu dengan rata rata nilai kekerasan tertinggi sebesar 108.66 HRB sedangkan variasi pendinginan udara memiliki ratarata nilai kekerasan tertinggi sebesar 109.88 HRB sedangkan pada variasi pendinginan oli hasil kekerasannya naik lebih tinggi yaitu dengan rata rata nilai kekerasan tertinggi sebesar 120.33 HRB. Struktur mikro besi cor nodular FCD 45 memiliki grafit yang berbentuk bulat (nodul),sedangkan besi tuang nodular yang sudah mengalami proses perlakuan panas austempering mengalami pengicilan nodul pada grafitnya dan jumlah bulatannya lebih merata dari pada sebelum mengalami perlakuan panas.
\end{abstract}

Kata kunci: Besi cor nodular, Austempering, Quenching

\section{PENDAHULUAN}

Perkembangan ilmu pengetahuan dan teknologi saat ini membawa dampak yang begitu besar bagi perkembangan teknologi, seiring dengan kemajuan dalam dunia industri, terutama industri di bidang otomotif dan permesinan. Berbagai kebutuhan terhadap material yang beraneka ragam telah memaksa manusia untuk berinovasi, baik dari pemilihan material sampai dengan pembaruan sifat - sifat material. Sehingga material logam yang paling banyak digunakan di dunia industri adalah baja, karena baja memiliki keunggulan yaitu kekuatan yang tinggi, kemampukerasan yang baik dan relatif ulet. Pada perkembangannya penggunaan material baja diimbangi dengan semakin banyaknya pengunaan material besi cor. Hal ini terjadi karena besi cor memiliki beberapa keunggulan dibandingkan baja, yaitu merupakan bahan yang relatif murah, memiliki sifat mampu cor (castability) yang baik, dan juga memiliki sifat mampu mesin (machinability) yang relatif lebih baik dibandingkan dengan baja.

Besi cor pada dasarnya merupakan paduan eutektik dari besi dan karbon. Dengan demikian temperatur lelehnya relatif lebih rendah, sekitar 1200 C. Temperatur leleh yang rendah sangat menguntungkan, karena mudah dicairkan, sehingga pemakaian bahan bakar atau energi lebih hemat dan murah. Selain itu dapur peleburannya dapat di bangun dengan lebih sederhana.

Besi cor dapat diklasifikasikan menjadi beberapa jenis, diantaranya besi cor kelabu, besi cor nodular, besi cor mampu tempa dan besi cor putih. Besi cor nodular adalah salah satu jenis besi cor mampu tempa yang bentuk grafitnya bulat, kekuatan dan keuletannya menjadi lebih baik. Penelitian besi cor nodular telah dilakukan oleh peneliti. Beberapa diantaranya digunakan sebagai dasar untuk mendukung pelaksanaan penelitian ini yaitu Kenawy dkk (2001) yang menunjukkan bahwa sifat mekanik (kekuatan, kekerasan, dan keuletan) besi cor nodular dipengaruhi oleh fraksi fasa ferit atau perlit dari matrik dan besarnya ukuran grafit. Jika fraksi fasa perlit semakin tinggi maka kekuatan dan kekerasan juga akan semakin tinggi. Selanjutnya jika ukuran grafit semakin besar maka kekuatan dan keuletan besi cor nodular akan semakin rendah. Sementara Van Vlack (1992) menyatakan bahwa sifat mekanik besi cor sangat dipengaruhi oleh struktur mikronya yaitu fasa matrik dan grafitnya. Struktur besi cor terbentuk karena terjadinya proses pembekuan dari besi cor cair $\left(1200{ }^{\circ} \mathrm{C}\right)$, strukturnya terdiri dari austenit dan sementit. Struktur mikro tersebut ditentukan oleh laju pendinginan, perlakuan saat cair, perlakuan panas dan unsur paduan. 
Untuk mendapatkan sifat mekanik yang lebih baik dari besi cor nodular dilakukan proses austempering. Proses austempering adalah proses transformasi yang terjadi secara isothermal, dimana dari proses tersebut akan dihasilkan material austempered ductile iron (ADI). Berkaitan dengan material ADI, penelitian ini bertujuan untuk mengetahui pengaruh austemper ductile iron terhadap kekerasan dan struktur mikro ductile cast iron FCD 45.

\section{TINJAUAN PUSTAKA}

Besi cor adalah salah satu jenis logam tertua dan murah yang pernah ditemukan umat manusia. Logam ini memiliki banyak aplikasi, sekitar 80 persen mesin kendaraan terbuat dari besi cor. Besi cor merupakan paduan antara unsur besi (Fe) dan karbon (C), Daerah komposisi kimia ditetapkan dalam diagram keseimbangan $\mathrm{Fe}-\mathrm{C}$ pada batas kelarutan karbon pada besi y, yaitu mengandung $2 \%$ karbon atau lebih, tetapi besi cor yang nyata terdiri dari paduan yang berkomponen banyak yang mengandung silikon (Si), mangan (Mn), fosfor $(\mathrm{P})$, belerang $(\mathrm{S})$ dan unsur-unsur lainnya walaupun sebenamya masih mengandung unsur-unsur lain namun tidak terlalu besar pengaruhnya (Surdia Tata, 1995).

Pada besi cor, karbon biasanya antara $2 \%-6,67 \%$, sedangkan pada baja hanya mencapai $2 \%$. Semakin tinggi kadar karbon yang ada pada besi cor akan mengakibatkan besi cor rapuh/getas. Selain dari karbon besi cor juga mengandung silikon (1-3\%), mangan (0,25-15\%), dan phosphor $(0,05-15 \%)$, selain itu juga terdapat unsur-unsur lain yang ditambahkan untuk mendapatkan sifat-sifat tertentu.

Selain unsur-unsur yang ditambahkan, dalam besi cor juga terdapat faktor-faktor penting lainnya yang dapat mempengaruhi sifat - sifat besi cor tersebut antara lain proses pembekuan, laju pendinginan dan perlakuan panas yang dilakukan. Besi cor mempunyai keuntungan yaitu mampu cor (castability) yang baik, kemudahan proses produksi dan rendahnya temperatur ruang, selain itu besi cor juga mempunyai sifat yang sulit dilakukan drawing atau diubah bentuknya pada temperatur kamar, akan tetapi besi cor mempunyai titik lebur yang relative rendah yakni $11500 \mathrm{C}-13000 \mathrm{C}$ dan dapat dicor kedalam bentuk - bentuk yang sulit. Hal ini merupakan keuntungan dari besi cor karena untuk mendapatkan bentuk benda yang diinginkananya diperlukan sedikit proses pemanasan. Dan juga besi cor mempunyai kekerasan, ketahanan aus dan ketahanan terhadap korosi yang cukup baik.

Besi cor terbuat dari besi kasar (Pig Iron) hasil tanur tinggi dari bijih besi. Kemudian besi kasar dilebur kembali agar bisa menjadi besi cor. Peleburan besi cor biasanya dilakukan dalam tungku yang sering disebut Kupola.

Bentuk dan konstruksi Kupola tersebut hampir sama dengan konstruksi tanur tinggi (Blast Furnace). Bahan baku yang dilebur terdiri dari batang logam besi kasar yang dihasilkan dari proses tanur tinggi. Bahan baku yang dilebur terdiri dari ingot besi kasar yang dihasilkan dari proses tanur tinggi, ditambah dengan skrap baja ataupun skrap besi cor (Return Scrap). Disamping itu penambahan bahan-bahan seperti ferosilikon (FeSi) dan feromangan (FeMn) sering pula dilakukan. Hal ini dimaksudkan untuk menaikkan kembali kadar Si dan Mn dalam besi cor karena sebagian dari kedua unsur tersebut biasanya berkurang (hilang) akibat oksidasi pada saat peleburan.

Bahan bakar yang digunakan adalah kokas dan dimasukkan ke dalam Kupola selang seling dengan muatan logam. Proses pembakaran terjadi dengan meniupkan udara ke dalam Kupola dengan menggunakan Blower. Untuk mendapatkan proses peleburan yang baik maka perbandingan antara muatan logam, bahan bakar dan kebutuhan udara harus dijaga sebaik mungkin.

Disamping membutuhkan bahan-bahan seperti yang disebutkan diatas, ke dalam Kupola juga ditambahkan sejumlah batu kapur. Bahan ini dapat membantu pembentukan terak (slag) yang dapat mengikat kotoran-kotoran sehingga memisahkannya dari besi cair.

Proses peleburan besi cor dengan Kupola biasanya terjadi secara kontinyu artinya begitu muatan logam mencair maka langsung mengalir keluar tungku. Logam cair yang keluar dari Kupola ditampung pada alat perapian depan (forehearth) yang kemudian diangkut dengan menggunakan ladel untuk dicor ke dalam cetakan. Dengan proses peleburan seperti itu maka sering kali mempersulit untuk melakukan pengaturan komposisi kimia. Hal ini dapat mengakibatkan daerah komposisi kimia yang dihasilkan menjadi lebar sehingga memberikan variasi pula terhadap kualitas produk yang dibuat.

Disamping itu kekurangan lainnya pada proses peleburan dengan Kupola yaitu logam cair mudah mengalami kontaminasi oleh sulfur atau unsur-unsur lainnya yang disebabkan oleh bahan bakar kokas. Pengotoran karena sulfur ini dapat menurunkan sifat-sifat besi cor.

Karena kekurangan-kekurangan di atas, maka dewasa ini banyak pabrik pengecoran menggunakan tungku listrik untuk menggantikan Kupola. Tungku listrik yang banyak digunakan adalah dari jenis tungku induksi. Bahan baku yang dilebur pada umumnya tidak menggunakan besi kasar melainkan sebagian besar berupa skrap baja atau skrap besi cor. Peleburan dengan tungku ini dapat menghasilkan logam cair dengan 
komposisi kimia yang lebih konsisten dengan kadar impuritas yang lebih rendah karena bahan baku yang dilebur biasanya berupa skrap baja, maka untuk menaikkan kadar karbon agar mencapai kadar yang sesuai untuk besi cor biasanya dilakukan dengan memasukkan sejumlah arang kayu ke dalam tungku.

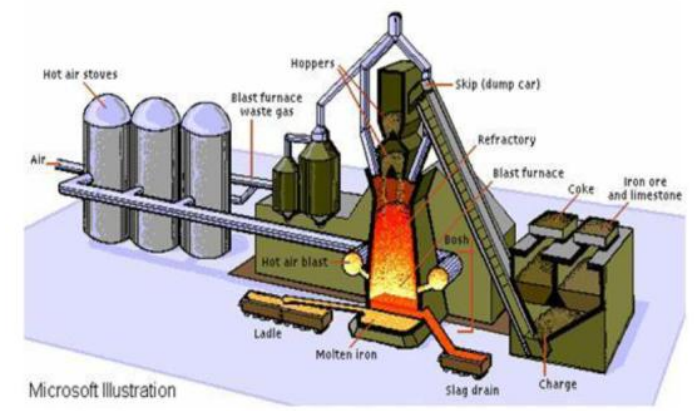

Gambar 1. Proses Pembuatan Besi Cor

Dalam pemakaian di industri, ada tiga jenis besi cor yang banyak digunakan, yaitu : besi cor kelabu (grey cast iron), besi cor ulet atau besi cor nodular (nodular cast iron) dan besi cor putih (white cast iron). Ketiga jenis besi cor ini mempunyai komposisi kimia yang hampir sama yaitu : 2,55 - 3,5 \%C, 1-3 \% Si, Mn kurang dari $1 \%$ sedangkan $\mathrm{S}$ dan $\mathrm{P}$ dibatasi antara 0,05-0,10 $\%$ (maksimum). Walaupun komposisi kimianya hampir sama, tetapi karena prosesnya berbeda maka struktur dan sifat-sifat dari ketiga besi cor tersebut berbeda.

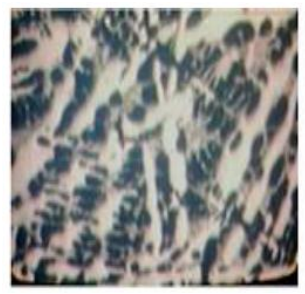

Gambar 2. Besi Cor Putih

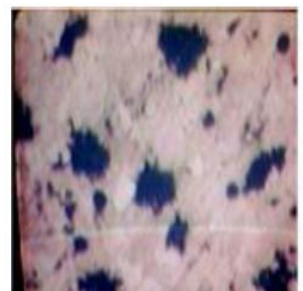

Gambar 3. Besi Cor Mampu Tempa

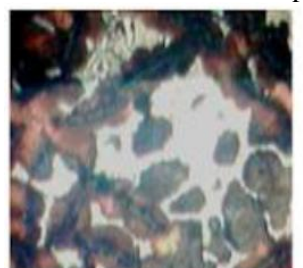

Gambar 4. Besi Cor Kelabu
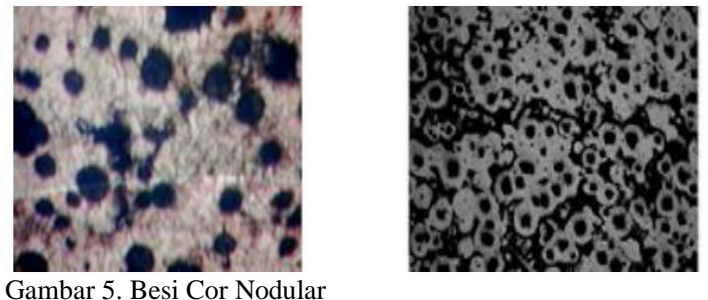

\section{Pengaruh Kandungan Kimia Besi Cor 1. Pengaruh Tembaga}

Tembaga adalah logam yang berwarna kemerahan dengan berat jenis 8,65 gr/cm3yang mempunyai titik lebur $10700 \mathrm{C}-11930 \mathrm{C}$ dan memiliki kekuatan tarik $200-400 \mathrm{~N} / \mathrm{mm} 2$. Tembaga sering digunakan dalam industri karena memiliki sifat - sifat yang menguntungkan antara lain adalah mempunyia sifat penghantar panas yang baik, memiliki keuletan yang tinggi (mudah dibentuk), serta memiliki ketahanan korosi yang baik. Penambahan tembaga sebagai unsur paduan pada besi cor biasanya berkisar antara 0,3\% sampai $1,5 \%$. Tembaga juga berfungsi sebagai penstabil grafit pada besi cor.

Tembaga secara khusus bernilai untuk mengurangi sensitivitas bagian, seperti menghasilkan besi kuat dan padat pada pusat bagian tebal tanpa meningkatkan kemungkinan chill pada bagian yang tipis. Tembaga juga dapat meningkatkan kedalaman herdenbility dengan meningkatkan kedalaman pengerasan untuk suatu kecepatan quench sebagai hasil efeknya terhadap laju transformasi pada titik perubahan austenit dan ferit. Tembaga mampu menaikkan kekerasan dasar dengan pembentukan larutan padat yang lebih keras dari pada besi tanpa paduan, dengan menjaga kestabilan pearlit dan memperhalus ukuran perlit. Tembaga tidak membentuk karbida bebas dimana efeknya terhadap ketahanan aus tidak beda jauh dengan efeknya dalam menekan pembentukan ferrit bebas, resiko untuk pembentukan besi dengan karbida dengan mechinability rendah dapat dikurangi. Penambahan tembaga tidak meningkatkan kedalaman kekerasan karena pada penambahan kecepatan atau quench faktor utama yang mempengaruhi kekerasan adalah kulit logam diatas temperatur kritis dan waktu dimana lapisan ini tetap pada temperatur sebelum quenching. Tembaga mempunyai batas kelarutan pada besi cor 3,0 \% - 3,5\% yang dapat dideteksi secara mikroskopik sebagai unsur terpisah yang mengandung $96 \%$ dan $4 \%$ besi. Tembaga menurunkan kandungan karbon dari besi karbon eutektik sekitar $0,075 \%$ tiap $1 \%$ tembaga. Tembaga menurunkan temperatur pembekuan dari besi cor sekitar 20C tiap $1 \%$ tambahan. Sedangkan nilai pengrafitan tembaga sekitar $0,2 \%$ - $0,35 \%$ dari silikon.

Dalam jumlah yang banyak tembaga digunakan untuk membentuk perlit bila ditambah 
paduan. Efek yang ditimbulkan tembaga relatif lebih lemah dibanding dengan paduan nikel karena keterbatasan larut tembaga dalam austenit yang hanya sekitar 2,5\% atau bahkan lebih rendah lagi. Keterbatasan ini menujukkan bahwa tembaga tidak dapat melengkapi paduan dalam nikel untuk jenis besi Cor $\mathrm{Ni}$ keras. Saat penambahan pada chilled iron tampa kromium, tembaga mendekati nilai transisi dari besi cor putih kebesi cor kelabu.

Tembaga lebih efektif untuk menahan perlit, saat digunakan didalam hubungan antara $0,5 \%$ - $2 \%$ kandungan Mo. Kekerasan yang dihasilkan dari paduan ini akan menghasilkan penahanan yang baik. Dimana indikasi ini tampak baik dan memberi efek yang sinergi saat tembaga ditambahkan pada besi cor. Tembaga dapat juga digunakan antara 3 hingga $10 \%$ merupakan jumlah yang sama pada high nikel graiy dan juga ductile iron. Digunakan pada bahan yang tahan korosi dan temperatur tinggi. Disini tembaga dapat meningkatkan ketahanan korosi yang utama tahan terhadap oksidasi atau kerak air.

\section{Pengaruh Karbon}

Kadar karbon tergantung dari jenis besi kasar yang digunakan, dan karbon yang diserap dari kokos selama peleburan. Di dalam besi cor, karbon bersenyawa dengan besi membentuk karbida besi atau dalam keadaan bebas sebagai grafit. Grafitisasi adalah proses dimana karbon yang terikat dalam besi yang disebut sementit berubah menjadi karbon bebas. Grafitasi akan mudah terjadi apabila kadar karbon dalam besi cor lebih dari 2\%. Pembentukan grafit juga tergantung pada laju pendinginan dan kadar silikon. Karbon sebagai unsur paling penting mempunyai pengaruh sangat besar terhadap sifat mekanik, seperti: kekuatan tarik, regangan patah, kekerasan, dll. Jumlah karbon di dalam besi cor kelabu sekitar 2-3,7 \%, dia menempatkan diri pada dua kondisi, yaitu membentuk senyawa kimia $\mathrm{Fe} 3 \mathrm{C}$ yang dikenal dengan sementit, dan dalam keadaan bebas yang dikenal dengan grafit.

\section{Pengaruh Silikon}

Silikon memiliki pengaruh yang cukup besar terhadap perubahan sifat mekanik. Karbon dan silikon mempunyai fungsi yang mirip, keduaduanya mendorong pembentukan grafit sehingga kandungan kedua unsur ditentukan berdasarkan harga tingkat kejenuhan karbon (sattigungsgrad). Silikon ditambahkan sekitar 1,4 - 2,3\% untuk menggalakkan pembentukan grafit. Silikon didalam besi menempatkan diri didalam ferit.

Kadar silikon yang tinggi memungkin kan pembentukan grafit, dimana grafit meningkatkan kemampuan pemesinan. Karbon efikalen merupakan penambahan silikon dan karbon dalam besi cor kelabu. Kadar silikon menentukan bagian karbon yang terikat dengan besi dan bagian yang terbentuk karbon bebas setelah tercapai keadaan seimbang. Kelebihan silikon membentuk ikatan yang keras dengan besi sehingga diatas $3,25 \%$ dapat meningkatkan kekerasan. Untuk besi cor yang besar menggunakan kadar silikon yang rendah. Untuk memperoleh paduan yang tahan terhadap korosi dan zat asam sebaiknya menggunakan silikon dengan kadar $13 \%$ sampai $17 \%$.

\section{Pengaruh Fosfor}

Fosfor di dalam besi cor kelabu hingga 0,3\% akan membentuk senyawa Fe3P dan mampu alir menjadi lebih tinggi karena suhu eutektik turun hingga 956oC. Phospor diperlukan untuk pembuatan benda cor tipis, namun pemberian terlalu banyak bisa mengakibatkan timbulnya lubang-lubang kecil pada permukaan maka kandungan phospor dibatasi antara 0,2-2,0\%.

Fosfor mencegah pembentukan grafit kalau kandungannya lebih dari $1 \%$. Struktur ini tidak menjadi halus meskipun dibawah pendinginan cepat. Penambahan kandungan fosfor mengurangi kelarutan karbon dan memperbanyak sementit pada kandungan karbon yang tetap, sehingga struktur menjadi keras dan sementit sukar terurai. Fosfor sulit beroksidasi serta dapat membentuk ikatan yang dikenal dengan nama steadit yaitu campuran besi dengan fosfida yang mempunyai sifat keras, rapuh dan mempunyai titik cair yang lebih rendah.

\section{Pengaruh unsur-unsur lainnya}

Belerang mengurangi kelarutan karbon dalam besi cor, dan meningkatkan penggrafitan. Tetapi kenyataannya penambahan belerang akan mengurangi grafit dan cenderung membentuk besi cor putih. Kecuali dalam kasus adanya mangan, belerang cenderung membentuk sulfide dan menggalakkan besi cor putih yang kadangkadang menyebabkan bintik-bintik keras. Mangan dibutuhkan untuk merangsang pembentukan struktur perlit, juga diperlukan untuk mengikat sulfur membentuk senyawa $\mathrm{MnS}$. Jumlah sekitar 0,5-0,7\%. Sebagai tambahan, unsur yang meninggikan penggrafitan adalah tembaga, nikel, aluminium, sementara unsur yang mencegah penggrafitan diantaranya adalah crom, dan molybdenum.

\section{METODE PENELITIAN}

Penelitian ini dilaksanakan di Laboratorium Uji Logam Fakultas Teknik Jurusan Mesin Universitas Merdeka Malang. Variabel penelitian dibagi menjadi dua bagian yaitu variabel bebas adalah quenching udara dan oli, sedangkan variabel terikatnya adalah nilai kekerasan dan mikrostruktur. Bahan yang digunakan dalam penelitian ini adalah Besi Cor 
Nodular FCD 45 tinggi $5 \mathrm{~mm}$ dan diameter 20 $\mathrm{mm}$. Adapun prosedur pengujian dalam penelitian ini yaitu dengan proses austempering, pengujian kekerasan dan pengujian metalografi (Struktur Mikro).

\section{Prosedur Austempering.}

1. Menyiapkan peralatan dan spesimen diletakkan pada alat yang sudah disediakan. Spesimen untuk masing-masing pengujian sebanyak 3 buah.

2. Semua sample uji dimasukan ke dalam dapur untuk mendapatkan perlakuan panas preheating $6000 \mathrm{C}$ selama 45 menit, kemudian temperatur dapur perlahan - lahan dinaikkan sampai temperatur austenisasi $9000 \mathrm{C}$ selama 45 menit/1 jam.

3. Proses terakhir yaitu pendinginan, dimana masing-masing spesimen pengujian dilakukan pendinginan menggunakan media udara terbuka, oli dan tanpa perlakuan.

\section{Prosedur Pengujian Kekerasan.}

1. Menyiapkan besi cor FCD 45 sebanyak 3 buah sebagai benda uji kekerasan.

2. Mengambil data awal setiap spesifikasi dari setiap besi cor sebelum mendapat perlakuan.

3. Menaruh benda uji pada bantalan penekanan identor mesin uji kekerasan.

4. Menyalakan mesin uji kekerasan.

5. Mengambil data akhir setelah mendapat perlakuan

\section{Prosedur Pengujian Metalografi.}

Setelah semua spesimen dilakukan perlakuan panas dan tanpa perlakuan maka selanjutnya dilakukan pengujian metalografi. Pengujian metallografi dilakukan untuk mengamati struktur mikro logam, selanjutnya pengujian ini akan menunjukan pengaruh yang ditimbulkan oleh proses austempering terhadap struktur mikro spesimen tersebut dan dengan hasil pengujian ini dapat di ambil kesimpulan tentang perubahan sifat yang di alami material akibat proses austempering. Adapun urutan dalam melakukan pengujian metalografi ini adalah sebagai berikut :

1. Menyiapkan besi cor FCD 45 sebanyak 3 buah sebagai benda uji metalografi.

2. Proses pengamplasan pada permukaan benda bertujuan untuk menghaluskan permukaan benda dan meratakan bidang permukaan benda yang miring .

3. Proses pemolesan yang bertujuan untuk meningkatkan tingkat kehalusan yang maksimal pada permukaan benda uji .

4. Proses pengetsaan dilakukan dengan menggunakan asam pikral yang bertujuan untuk menunjukan adanya butiran - butiran kristal pada logam setelah pengambilan gambar.

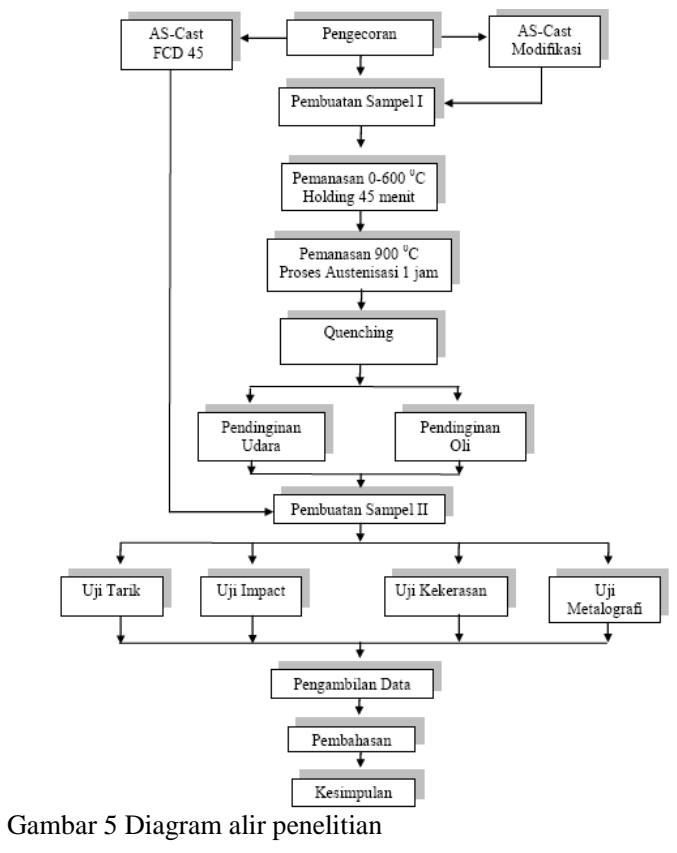

HASIL DAN PEMBAHASAN

Hasil pengujian ditampilkan pada Tabel 1 dan Gambar 6 berikut.

Tabel 1 Data hasil Uji Rockwell

\begin{tabular}{|c|c|c|}
\hline Perlakuan & Spesimen & Nilai Rockwell \\
\hline \multirow{9}{*}{$\begin{array}{l}\text { Pendinginan } \\
\text { Udara }\end{array}$} & \multirow{3}{*}{1} & 107 \\
\hline & & 110 \\
\hline & & 110 \\
\hline & \multirow{3}{*}{2} & 110 \\
\hline & & 111 \\
\hline & & 112 \\
\hline & \multirow{3}{*}{3} & 110 \\
\hline & & 109 \\
\hline & & 110 \\
\hline \multirow{9}{*}{$\begin{array}{l}\text { Pendinginan } \\
\text { Oli }\end{array}$} & \multirow{3}{*}{1} & 116 \\
\hline & & 115 \\
\hline & & 115 \\
\hline & \multirow{3}{*}{2} & 121 \\
\hline & & 122 \\
\hline & & 123 \\
\hline & \multirow{3}{*}{3} & 125 \\
\hline & & 123 \\
\hline & & 123 \\
\hline \multirow{9}{*}{ Tanpa perlakuan } & \multirow{3}{*}{1} & 108 \\
\hline & & 108 \\
\hline & & 107 \\
\hline & \multirow{3}{*}{2} & 110 \\
\hline & & 110 \\
\hline & & 110 \\
\hline & \multirow{3}{*}{3} & 108 \\
\hline & & 108 \\
\hline & & 109 \\
\hline
\end{tabular}



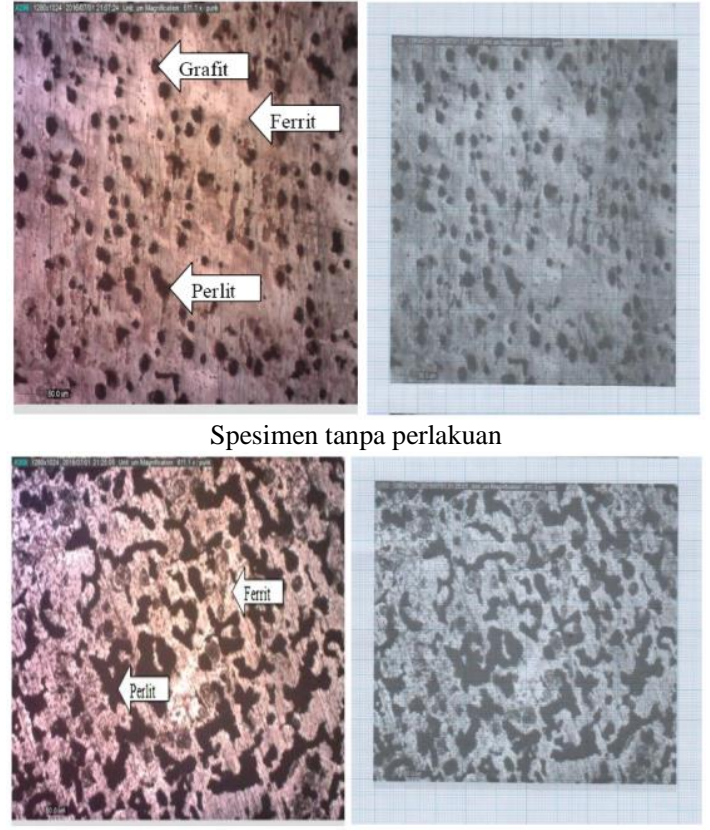

Spesimen pendinginan udara

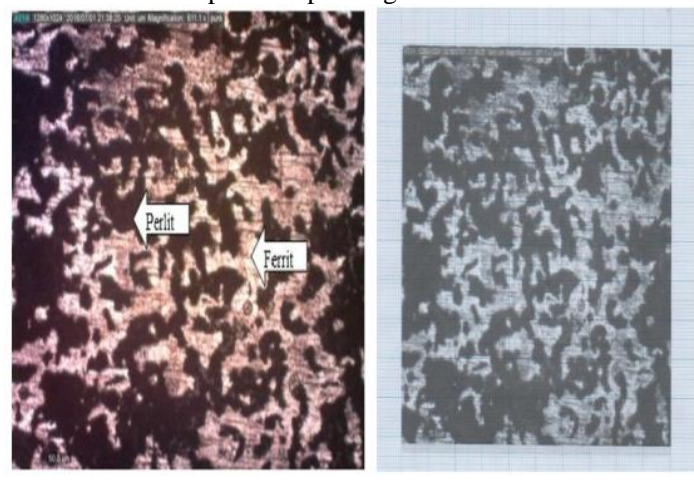

Spesimen pendinginan oli

Gambar 6. Hasil uji mikrostruktur besi cor nodular FCD 45

Berdasarkan pengamatan metalografi hasil struktur mikro besi cor nodular FCD 45 tanpa perlakuan yang ditunjukkan pada gambar di atas terlihat bahwa struktur mikro yang terjadi pada spesimen tersebut terdiri dari grafit yang masih berbentuk bulat (nodul) dan matrik. Sehingga pada spesimen tersebut matrik yang terbentuk adalah ferrit dan perlit, dimana prosentase matrik ferrit (warna putih ke abuabuan) lebih cenderung mengalami kenaikan prosentase yaitu $89,03 \%$ bila dibandingkan dengan matrik perlit (berwana gelap kehitaman) yang mengalami penurunan prosentase yaitu 19,85\%. Matrik ferit memiliki sifat ulet dan lunak sedangkan matrik perlit memiliki kekerasan yang lebih tinggi namun getas.

Hasil pengamatan metalografi menunjuk kan bahwa struktur mikro pada spesimen besi cor nodular FCD 45 dengan menggunakan media pendinginan udara setelah melalui proses perlakuan panas dengan variasi temperatur $600^{\circ} \mathrm{C}$ - $900^{\circ} \mathrm{C}$ telah mengalami perubahan grafit dan matrik dimana matrik yang terbentuk adalah matrik perlit yang merupakan campuran antara ferit dan simentit yang tersebar merata pada suluruh penampang besi cor sehingga nilai prosentase dari ke dua matrik tersebut hampir sama besar dimana prosentase matrik perlit $44,83 \%$ dan matrik ferrit sebesar 58,17\%, hal ini terjadi karena struktur perlit berasal dari perubahan austenisasi pada pendinginan udara setelah melewati temperatur kritis.

Hasil pengamatan metalografi menunjuk kan bahwa struktur mikro pada spesimen besi cor nodular FCD 45 dengan menggunakan media pendinginan oli terlihat bahwa matrik perlit yang berwarna gelap kehitaman terlihat lebih banyak dan cenderung mengalami kenaikan nilai prosentase perlit yaitu sebesar 70,55\% dan hampir dominan bila dibandingkan dengan matrik ferrit yang berwarna putih keabu-abuan dengan prosentase nilai ferrit $30,25 \%$, hal ini di karenakan grafit nodul yang berbentuk bulat pada pemanasan $600^{\circ} \mathrm{Csampai} 900^{\circ} \mathrm{C}$ telah mencapai titik austenisasi dimana fase yang terbentuk lebih banyak adalah perlit yang mengakibatkan benda menjadi lebih keras.

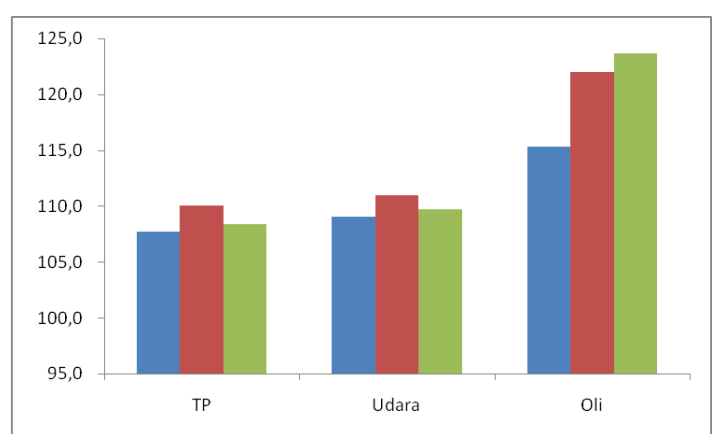

Gambar 7. Perbandingan nilai rata-rata 3 sampel pengujian untuk spesimen tanpa perlakuan (TP), pendinginan udara, dan pendinginan oli,

Dari hasil pengujian Ductile Cast Iron (FCD 45) terhadap kekerasan dengan variasi tanpa perlakuan, pendinginan udara dan pendinginan oli didapatkan hasil yang berbedabeda, yaitu dimana pada proses tanpa perlakuan kekerasan besi cor FCD 45 lebih cenderung mengalami penurunan yaitu dengan jumlah harga kekerasan sebesar 325.99 HRB dan rata rata nilai kekerasan tertinggi tanpa perlakuan sebesar 108.66 HRB.

Variasi pendinginan udara memiliki harga kekerasan sebesar 329.66 HRB dan ratarata nilai kekerasan tertinggi sebesar $109.88 \mathrm{HRB}$ sedangkan pada variasi pendinginan oli hasil kekerasannya naik lebih tinggi dibandingkan dengan pendinginan udara dan tanpa perlakuan yaitu jumlah harga kekerasan sebesar 360.99 HRB dan rata rata nilai kekerasan tertinggi sebesar 120.33 HRB. Hal ini terjadi karena pendinginan udara dan pendinginan oli, telah terlebih dahulu diproses austempering di dalam dapur pemanas dengan variasi temperature $600^{\circ} \mathrm{C}$ - $900^{\circ} \mathrm{C}$ dengan proses penahanan waktu (holding 
time) selama 45 menit atau 1 jam terhadap kekerasan yang kemudian diquenching.

Menurut hasil analisa pengujian kekerasan yang telah dilakukan, apabila semakin cepat logam didinginkan pada media pendingin yang bersifat sangat cepat maka akan semakin keras pula sifat logam tersebut. Karena karbon yang dihasilkan dari pendinginan cepat lebih banyak dari pendinginan lambat. Hal ini disebabkan karena atom karbon tidak sempat berdifusi keluar dan terjebak dalam struktur kristal dan membentuk struktur tetagonal yang ruang kosong antar atomnya kecil, sehingga kekerasannya meningkat.

\section{PENUTUP}

Pengujian kekerasan besi cor nodular FCD 45 dengan menggunakan media pendinginan udara, oli dan tanpa perlakuan didapatkan hasil sebagai berikut yaitu :

1) Tanpa perlakuan memiliki harga kekerasan sebesar 325.99 HRB dan rata rata nilai kekerasan tertinggi sebesar 108.66 HRB .

2) Pendinginan udara memiliki harga kekerasan sebesar 329.66 HRB dan rata-rata nilai kekerasan tertinggi sebesar 109.88 HRB .

3) Pendinginan oli hasil kekerasannya naik lebih tinggi dibandingkan dengan pendinginan udara dan tanpa perlakuan yaitu dengan jumlah harga kekerasan sebesar 360.99 HRB dan rata rata nilai kekerasan tertinggi sebesar 120.33 HRB.

Variasi temperature $600^{\circ} \mathrm{C}-900^{\circ} \mathrm{C}$ dengan penahanan waktu (holding time) selama 45 menit atau 1 jam, dapat mempengaruhi perubahan struktur yang terdapat pada besi cor nodular FCD 45 sehingga terlihat dari data yang di ambil terjadi kenaikan tingkat kekerasan dan perubahan struktur mikro yang berbeda-beda. Struktur mikro yang terjadi pada pendinginan oli memiliki perlite dan grafit lebih banyak dari pada struktur mikro ferrit.

\section{DAFTAR PUSTAKA}

Vlack Lawrence H. Van. 1992. Ilmu dan Teknologi Bahan. Jakarta.Erlangga.

Kenawy, M.A., Abdel-Fattah, A.M., Okasha, N., and El-Gazery, M., 2001, Mechanical and Structural Properties of Ductile Cast Iron , Egypt. J. Sol, Vol. 24-No.2, pp. 151-158.

Raharjo, Wahyu Purjo., Surojo, Eko. Pengaruh Temperatur Dan Austenisasi Terhadap Struktur Mikro Dan Kekerasan Besi Cor Nodular FCD 45. Skripsi, Program Sarjana Jurusan Teknik Mesin Universitas Sebelas Maret. Surakarta, 2006.

Suratman, R., 1994, Panduan Proses Perlakuan Panas, Lembaga Penelitian-ITB, Bandung.

http://bobbygunadarma.blogspot.co.id/2010/09/tulisan2ilmu-logam-pengecoran-logam.html

http://www.infometrik.com/2011/08/perlakuanpanas-logam-1-diagram-fasa

http://sonjaya45.wordpress.com/2010/03/13/besicor/

http://ardra.biz/metalurgi/besi-cor-cast-iron 